\title{
Chemical and strontium isotope characterization of rainwater at an urban site in Loess Plateau, Northwest China
}

\author{
Zhifang $\mathrm{Xu}^{\mathrm{a}, *}$, Yushan $\mathrm{Li}^{\mathrm{b}, \mathrm{c}}$, Yang Tang ${ }^{\mathrm{b}, \mathrm{d}}$, Guilin Han ${ }^{\mathrm{d}}$ \\ ${ }^{a}$ Key Laboratory of Engineering Geomechanics, Institute of Geology and Geophysics, Chinese Academy of Sciences, P.O. Box 9825, Beijing 100029, China \\ b Graduate University of Chinese Academy of Sciences, Beijing 100049, China \\ ${ }^{c}$ Research Center for Eco-Environmental Sciences, Chinese Academy of Sciences, Beijing 100085, China \\ d State Key Laboratory of Environmental Geochemistry, Institute of Geochemistry, Chinese Academy of Sciences, Guiyang, Guizhou 550002, China
}

\section{A R T I C L E I N F O}

\section{Article history:}

Received 4 February 2009

Received in revised form 10 July 2009

Accepted 27 July 2009

\section{Keywords:}

Major ions

Strontium isotope

Alkaline rain

Lanzhou

Loess Plateau

\begin{abstract}
A B S T R A C T
Major ion concentrations and strontium isotopic ratios $\left({ }^{87} \mathrm{Sr} /{ }^{86} \mathrm{Sr}\right.$ ) were measured in rainwater samples collected at the urban site of Lanzhou, a city located on the Loess Plateau in the arid and semiarid areas of northwest China. The rainwater samples possessed alkaline $\mathrm{pH}$, at a reference level of 5.6, with a range of 6.82 to 8.28 and a volume-weighted mean (VWM) pH value of 7.70. The alkaline character of rainwater in Lanzhou is due to the result of neutralization caused by the alkaline soil dusts which contain large amount of $\mathrm{CaCO}_{3}$. It was observed that $\mathrm{Ca}^{2+}$ was the most abundant cation with a VWM value of $886 \mu$ eq $\mathrm{l}^{-1}$ (115-2184 $\mu \mathrm{eq} \mathrm{l}^{-1}$ ), accounting for $87.8 \%$ of the total cations. Without considering $\mathrm{HCO}_{3}^{-}, \mathrm{SO}_{4}^{2-}$ and $\mathrm{NO}_{3}^{-}$were dominant among the anions, accounting for $64.2 \%$ and $23.0 \%$, respectively, of the total measured anions. Using $\mathrm{Na}$ as an indicator of marine origin and $\mathrm{Al}$ for terrestrial inputs, the proportions of sea salt and non-sea-salt elements were estimated from elemental ratios. The precipitation in this region has typical continental characteristics. The $\mathrm{Sr}$ concentrations varied from 0.004 to $0.885 \mu \mathrm{mol} \mathrm{l}^{-1}$, and strontium isotopic ratios $\left({ }^{87} \mathrm{Sr} /{ }^{86} \mathrm{Sr}\right.$ ) lay in the range of $0.71025-0.71302$, with an average of 0.71143 . The ${ }^{87} \mathrm{Sr} /{ }^{86} \mathrm{Sr}$ ratios of Lanzhou rainwater are higher than that of seawater, which reflects contributions from the radiogenic Sr sources of the aerosols. The most suitable candidate for the source would be the soil dust originating from local and distant loess and desert areas. The ${ }^{87} \mathrm{Sr} /{ }^{86} \mathrm{Sr}$ ratios were used to characterize different sources of base cations in rainwater, suggesting that the samples could be interpreted in terms of combinations of at least three components: soil dust derived from the Loess Plateau and desert areas in northwest China (with ${ }^{87} \mathrm{Sr} /{ }^{86} \mathrm{Sr} \sim 0.7130$ ), seawater (with ${ }^{87} \mathrm{Sr} /{ }^{86} \mathrm{Sr} \sim 0.70917$ ), and anthropogenic inputs (with ${ }^{87} \mathrm{Sr}$ / ${ }^{86} \mathrm{Sr} \sim 0.7103$ ). The high ${ }^{87} \mathrm{Sr} /{ }^{86} \mathrm{Sr}$ ratio and $\mathrm{Ca}$ and $\mathrm{Sr}$ content in the rainwater from Lanzhou can be attributed to the dissolution of calcium carbonate in soil dust.
\end{abstract}

(c) 2009 Elsevier B.V. All rights reserved.

\section{Introduction}

Emissions of $\mathrm{SO}_{2}$ in China are increasing in tandem with the nation's rapid economic growth and its related systems of energy consumption and production, leading to significant deposition of acid rain in the south of China (Larssen et al., 2006). The chemistry of precipitation has been widely investigated in many areas in China, which have been

\footnotetext{
* Corresponding author. Tel./fax: +86 1082998289.

E-mail address: zfxu@mail.iggcas.ac.cn (Z.Xu).
}

significantly affected by acid rain during the last three decades. Most studies have focused on the distribution of precipitation $\mathrm{pH}$ and sulfur deposition (Zhao et al., 1988; Wang and Wang, 1995; Yu et al., 1998; Feng et al., 2001; Larssen et al., 2006; Aas et al., 2007; Huang et al., 2008). In China, the estimated emissions of $\mathrm{SO}_{2}$ into the atmosphere were about 22 million tons in 2003 (Larssen et al., 2006). However, the environmental impacts in Europe and North America associated with such high levels of strong acids in precipitation have not been widely detected in China. This is partly due to the fact that acid deposition is heavily 
influenced and modified by natural soil dust from the desert and semi-arid areas in northwest China (Fig. 1). As a result of the dissolution of carbonate minerals in soil dust, acid rain has not been recorded in northern China despite large emissions of acidic pollutants (Zhao et al., 1988). Larssen and Carmichael (2000) reported the high pH level problem in arid areas of China and noted that "data on base cations deposition are still scarce, and there remain large uncertainties regarding the sources of base cations."

Furthermore, various sources of the dissolved components in rainwater can generally be divided into three groups: (a) sea salt aerosols; (b) terrestrial aerosols (soil dust, biological emissions); and (c) anthropogenic inputs (industry, agriculture and fertilizers, combustion of fossil fuels) (Negrel and Roy, 1998). It is usually difficult to unravel the different sources, unless isotopes are used (Andersson et al., 1990). Strontium isotopes $\left({ }^{87} \mathrm{Sr} /{ }^{86} \mathrm{Sr}\right)$ are expected to provide insights into the source of base cations in rainwater; however, only a few data are available on the ${ }^{87} \mathrm{Sr} /{ }^{86} \mathrm{Sr}$ ratio in rainwater, which may result in a limitation in the use of $\mathrm{Sr}$ isotopes in atmospheric geochemistry (Nakano and Tanaka, 1997).

This paper presents for the first time the characteristics of the strontium isotope of rainwater collected during the rainy season in Lanzhou, a city located in the arid and semi-arid areas of northwest China. The purpose of this paper is to present and discuss the chemical and $\mathrm{Sr}$ isotopic characteristics of rainwater, to identify possible sources of the various components in precipitation, and to propose the cause or causes of alkaline rain in the region.

\section{Methods}

\subsection{Study area}

Loess soils and deserts cover a vast area in the arid and semiarid regions of northwest China. Lanzhou is located on the Loess Plateau (Fig. 1) with an average elevation of $1520 \mathrm{~m}$ and an area of $14,000 \mathrm{~km}^{2}$. It is the capital of Gansu Province, with a population of 2.6 million. The topography is characterized by valleys, basins, hilly land, and Huangtumao ditches and gully areas. The Yellow River flows through the entire city. The area has a semi-dry climate in the temperate zone with a mean annual temperature about $10{ }^{\circ} \mathrm{C}$, and average annual precipitation of $331 \mathrm{~mm}$. The majority of rain events occur between June and October. Lanzhou is one of the most important industrial cities in China and extremely polluted in terms of $\mathrm{SO}_{2}$. It is rich in coal and mineral resources, and has been dubbed as Gold City. The area also possesses various other metal resources, including silver, zinc, nickel, and manganese. Its oil refineries and chemical and metallurgical industries rank highest in China.

\subsection{Sample collection and analysis}

The rainwater samples were collected in the central part ( $36^{\circ} 03^{\prime} \mathrm{N} ; 103^{\circ} 51^{\prime} \mathrm{E}$ ) of Lanzhou City. The sampling collector was placed on the roof of a building about $15 \mathrm{~m}$ high from ground level in the Lanzhou Institute of Geology, Chinese Academy of Sciences. The rainwater samples were collected manually from the beginning of each rain event with a funnel

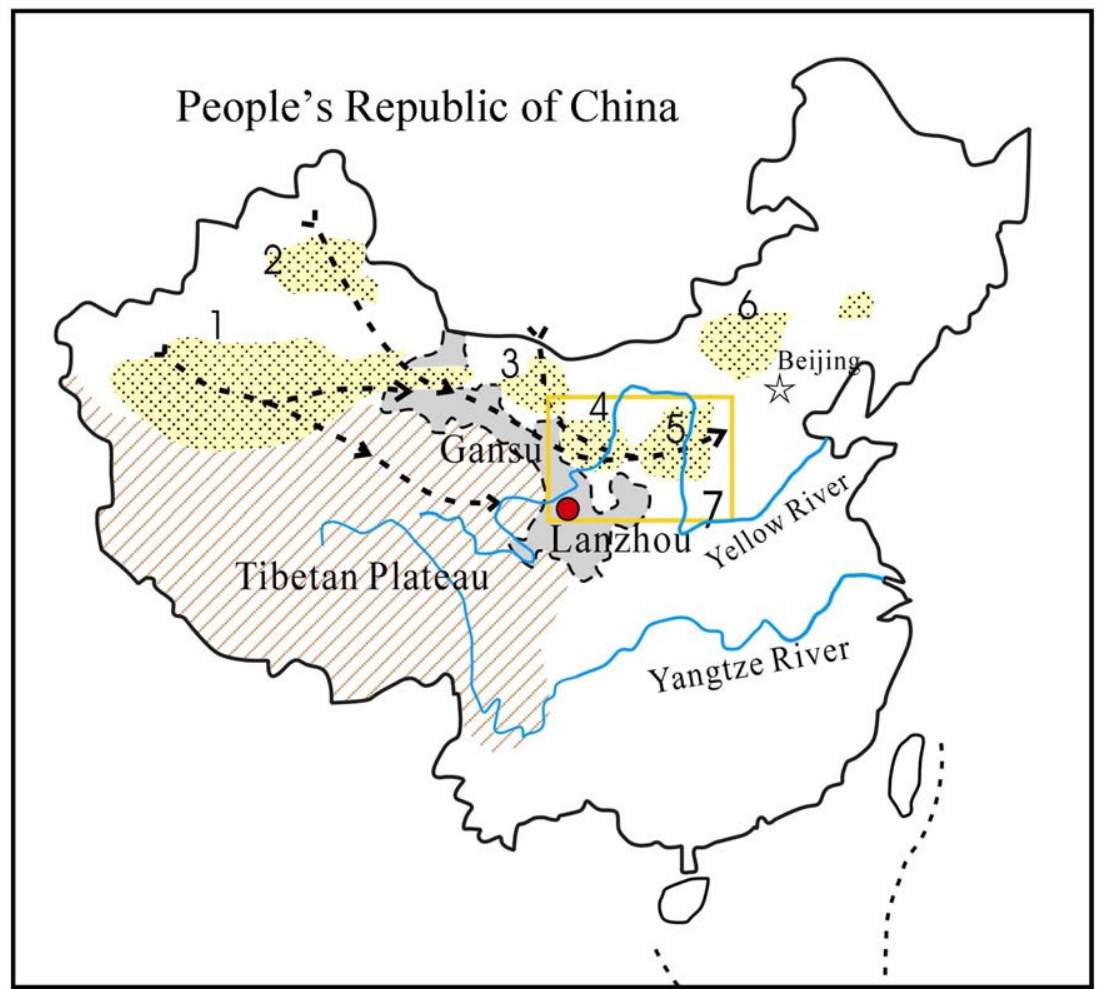

Fig. 1. Sketch map showing the sampling location, the Loess Plateau, and desert areas in northwest China. 1. Taklamakan Desert; 2 . Gurbantonggut Desert; 3. Badain Jaran Desert; 4. Tungeli Desert; 5. Muus Desert; 6. Hunshandake Desert; 7. Loess Region. The forward trajectories indicate the sources of soil dust and the routes of its transportation. 
collector that was located approximately $120 \mathrm{~cm}$ above the roof of the building. Prior to use, the collector was cleaned with hydrochloric acid (2-3 M), then thoroughly rinsed with Milli-Q water $(18.2 \mathrm{M} \Omega \mathrm{cm})$ and dried. To prevent any contamination from dry deposition, the collector was covered with a plastic lid, which was removed just before the onset of rainfall. A total of 23 rainwater samples were collected in the rainy season from June to October in 2007. The total precipitation of the events measured for this study was $285 \mathrm{~mm}$, accounting for approximately $73 \%$ of the annual precipitation of the same year.

The $\mathrm{pH}$ and conductivity were instantaneously measured at the end of a rain event at the sampling site with a portable $\mathrm{pH}$ and salt conductivity meter. The samples were then filtered through $0.22 \mu \mathrm{m}$ Millipore membrane filters using a pre-cleaned Nalgene filter apparatus, and the filtrate was separated into two aliquots. One was stored directly in a $50 \mathrm{ml}$ polyethylene bottle for measuring anions and the other was acidified with ultra-purified nitric acid to a pH less than 2 and stored in a pre-cleaned $200 \mathrm{ml}$ polyethylene bottle for measuring cations, $\mathrm{Al}$ and $\mathrm{Sr}$ concentrations, and $\mathrm{Sr}$ isotopic ratios. Major anions $\left(\mathrm{F}^{-}, \mathrm{Cl}^{-}, \mathrm{SO}_{4}^{2-}\right.$, and $\mathrm{NO}_{3}^{-}$) were measured by using ionic chromatography (Dionex DX-120). $\mathrm{NH}_{4}^{+}$concentration was determined by spectrophotometry using the Nessler method. Major cations $\left(\mathrm{K}^{+}, \mathrm{Na}^{+}, \mathrm{Ca}^{2+}\right.$, and $\mathrm{Mg}^{2+}$ ) were determined by ICP-AES (Thermo's IRIS Intrepid II). The concentrations of $\mathrm{Al}^{3+}$ and $\mathrm{Sr}^{2+}$ were measured by ICPMS (VG POEMS III) in the State Key Laboratory of Geological Processes and Mineral Resources, China University of Geosciences, Wuhan. Reagent and procedural blanks were determined in parallel to the sample treatment using identical procedures; analytical precision was better than $\pm 5 \%$.

The ${ }^{87} \mathrm{Sr} /{ }^{86} \mathrm{Sr}$ isotopic ratio was determined by a VG-354 mass spectrometer with five Faraday collectors in the State Key Laboratory of Environmental Geochemistry, Institute of Geochemistry, Chinese Academy of Sciences, Guiyang. Strontium in rainwater was pre-concentrated by partial evaporation and then purified by standard cation-exchange procedure in an ultra-clean laboratory. $\mathrm{Rb}$ and $\mathrm{Sr}$ were first separated from the samples on a cation-exchange column loaded with Dowex 50W-X8 200-400 mesh resins by elution of $2.0 \mathrm{M} \mathrm{HCl}$. In most cases, this technique resulted in $\mathrm{Sr}$ fractions with only small $\mathrm{Rb}$ interference. Full procedural blank for this technique amounted to less than $100 \mathrm{pg}$ of $\mathrm{Sr}$. The reproducibility was verified by periodic determinations of the NBS987 strontium standard. The average ${ }^{87} \mathrm{Sr} /{ }^{86} \mathrm{Sr}$ ratio of this standard for 25 determinations was $0.710238 \pm$ $0.000020(2 \sigma, n=25)$ during the course of the study.

\section{Results and discussion}

\subsection{Ionic composition}

Concentrations of the major ions and trace elements, and $\mathrm{Sr}$ isotopic ratios of rainwater samples are listed in Table 1 . The equivalent ratio of the sum of anions to that of cations ( $\Sigma_{\text {anions }}$ ) $\left.\Sigma_{\text {cations }}\right)$ is usually regarded as an indicator of the completeness of the measured major constituents (Al-Khashman, 2005; Li et al., 2007). The average $\Sigma_{\text {anions }} / \Sigma_{\text {cations }}$ ratio was 0.40 in this study, suggesting that at least one major anion was missing. Since the soil and sands in the arid and semi-arid regions of northern China are calcareous and alkaline (Zhang et al., 1995; Zhang et al., 2003b; Yokoo et al., 2004), the observed anion deficiency is most likely due to the exclusion of $\mathrm{HCO}_{3}^{-}$and $\mathrm{CO}_{3}^{2-}$ from the measurements (Al-Khashman, 2005). Li et al. (2007) also reported a similar $\Sigma_{\text {anions }} / \Sigma_{\text {cations }}$ ratio (0.37, without measuring $\mathrm{HCO}_{3}^{-}$content) in the case of studying the precipitation in Nam Co region in northwest China. By computing the concentration of $\mathrm{HCO}_{3}^{-}$(Avila, 1996), the average $\Sigma_{\text {anions }} / \Sigma_{\text {cations }}$ ratio was raised to about 0.77. Lanzhou is an important industrial city, so the deficiency may also be attributed to unmeasured organic anions, such as $\mathrm{HCOO}^{-}$and $\mathrm{CH}_{3} \mathrm{COO}^{-}$.

The volume-weighted mean (VWM) concentration of the ionic compositions and the statistical analyses are given in Table 2. Among the cations, $\mathrm{Ca}^{2+}$ is the most abundant with a VWM concentration of $886 \mu \mathrm{eq} \mathrm{l}^{-1}$, accounting for $87.8 \%$ of the total cations. Without considering $\mathrm{HCO}_{3}^{-}, \mathrm{SO}_{4}^{2-}$ and $\mathrm{NO}_{3}^{-}$ are dominant among the anions, accounting for $64.2 \%$ and $23.0 \%$, respectively, of the total measured anions. The volume-weighted means are commonly less than arithmetic means, indicating a higher concentration of ions usually associated with lower precipitation. Standard deviation (S.D.) calculations on the data show a larger dispersion of the values around the mean, which reveal greater variation in levels of ionic compositions of rainwater.

\subsection{Variation of $p H$}

Natural precipitation in a clean atmosphere is generally considered to be weakly acidic (Charlson and Rodhe, 1982; Galloway et al., 1993). However, a number of studies revealed that alkaline rain was common in arid and semi-arid regions (Berner and Berner, 1987; Sequeira, 1993; Kumar et al., 2002; Zhang et al., 2003b; Mouli et al., 2005; Al-Khashman, 2005; Li et al., 2007). All rainwater samples in this study were alkaline with a VWM pH of 7.70, ranging from 6.82 to 8.28. The cause of alkaline rain might be explained by the local and remote transport of soil dust, which contains a large fraction of calcite. Zhang et al. (2003b) reported the results of leaching experiments on the dusts collected in northwest China with de-ionized water. Their results showed that the dusts were all alkaline and the $\mathrm{pH}$ values (7.5-8.7) of the water collected were similar to those of the rainwater in Lanzhou. The observed major ions concentrations and $\mathrm{pH}$ values in rainwater from Lanzhou have been compared with the available data from other regions in China and the world (Table 3). Compared with other sites, the data from Lanzhou show the highest $\mathrm{pH}$ and $\mathrm{Ca}^{2+}$ concentration; $\mathrm{SO}_{4}^{2-}$ and $\mathrm{NO}_{3}^{-}$concentrations in the rainwater are also higher than those of other sites, and only lower than those of Beijing. Of particular note is the fact that the rainwater samples from Lanzhou are more mineralized than those from remote areas (Lasha and Nam Co regions) in the Tibetan Plateau. Thus, it is obvious that the relatively high $\mathrm{pH}$ values of rainwater in Lanzhou are not due to the lack of acidic ions in precipitation, but rather due to the neutralization of acidity by alkaline substances (mainly $\mathrm{Ca}^{2+}$ ). This neutralization is further confirmed by the correlation among the ions (Table 4). For example, no obvious correlations between $\mathrm{OH}^{-}$and $\mathrm{SO}_{4}^{2-}$ and $\mathrm{NO}_{3}^{-}(r=0.02$ and -0.12 , respectively $)$ indicate that most $\mathrm{SO}_{4}^{2-}$ and $\mathrm{NO}_{3}^{-}$are present as salts rather than as $\mathrm{H}_{2} \mathrm{SO}_{4}$ and $\mathrm{HNO}_{3}$. However, positive correlations are obtained between $\mathrm{OH}^{-}$and $\mathrm{Ca}^{2+}(r=0.60)$, between $\mathrm{SO}_{4}^{2-}$ and $\mathrm{Ca}^{2+}$ and $\mathrm{Mg}^{2+}(r=0.70$ and 0.88 , respectively) and between $\mathrm{NO}_{3}^{-}$and $\mathrm{Ca}^{2+}$ and $\mathrm{Mg}^{2+}(r=0.61$ and 0.87 , respectively). These correlations, therefore, indicate that acidic anions are neutralized 
Table 1

Concentrations of major ion (in $\mu \mathrm{eq} \mathrm{l}^{-1}$ ) and trace element $\mathrm{Al}$ and $\mathrm{Sr}$ (in $\mu \mathrm{mol} \mathrm{l}^{-1}$ ), and ${ }^{87} \mathrm{Sr} /{ }^{86} \mathrm{Sr}$ ratios in rainwaters from Lanzhou.

\begin{tabular}{|c|c|c|c|c|c|c|c|c|c|c|c|c|c|c|c|c|c|}
\hline \multirow{2}{*}{$\begin{array}{l}\text { Sample } \\
\text { number }\end{array}$} & \multirow{2}{*}{$\begin{array}{l}\text { Date } \\
\text { d-m- } \\
\text { yr }\end{array}$} & \multirow[t]{2}{*}{$\mathrm{pH}$} & \multirow{2}{*}{$\frac{\mathrm{EC}}{\mu \mathrm{S} \mathrm{cm} \mathrm{cm}^{-1}}$} & \multirow{2}{*}{$\frac{\mathrm{F}^{-}}{\mu \mathrm{eq} \mathrm{l}^{-1}}$} & \multirow{2}{*}{$\frac{\mathrm{Cl}^{-}}{\mu \mathrm{eq}}$} & \multirow[t]{2}{*}{$\mathrm{NO}_{3}^{-}$} & \multirow[t]{2}{*}{$\mathrm{SO}_{4}^{2-}$} & \multirow{2}{*}{$-\frac{\mathrm{NH}_{4}^{+}}{\mu e q \mathrm{I}^{-1}}$} & \multirow{2}{*}{$\frac{\mathrm{K}^{+}}{\mu \mathrm{eq} \mathrm{l}^{-1}}$} & \multirow{2}{*}{$\frac{\mathrm{Na}^{+}}{\mu \mathrm{eq} \mathrm{l}^{-1}}$} & \multirow{2}{*}{$\frac{\mathrm{Ca}^{2+}}{\mu e q \mathrm{l}^{-1}}$} & \multirow{2}{*}{$\frac{\mathrm{Mg}^{2+}}{\mu e q \mathrm{l}^{-1}}$} & \multirow{2}{*}{$\frac{\mathrm{Al}}{\mu \mathrm{mol} \mathrm{l^{-1 }}}$} & \multirow{2}{*}{$\frac{\mathrm{Sr}}{\mu \mathrm{mol} \mathrm{l^{-1 }}}$} & \multirow{2}{*}{${ }^{87} \mathrm{Sr} /{ }^{86} \mathrm{Sr}$} & \multirow[t]{2}{*}{$2 \sigma$} & \multirow{2}{*}{$\sum_{\text {cations }}$} \\
\hline & & & & & & & & & & & & & & & & & \\
\hline LZR-1 & $\begin{array}{l}15-06- \\
2007\end{array}$ & -8.11 & 214 & 32.5 & 53.1 & 216 & 554 & 25.6 & 14.8 & 29.1 & 2114 & 99.5 & 0.80 & 0.86 & 0.711617 & 13 & 0.37 \\
\hline LZR-2 & $\begin{array}{l}16-06- \\
2007\end{array}$ & -8.22 & 119 & 4.32 & 6.52 & 4.95 & 48.1 & 67.3 & 6.91 & 1.74 & 1222 & 27.5 & 0.46 & 0.23 & 0.712860 & 11 & 0.05 \\
\hline LZR-3 & $\begin{array}{l}17-06- \\
2007\end{array}$ & -8.23 & 120 & 7.79 & 12.4 & 11.5 & 104 & 65.5 & 1.02 & 9.13 & 1222 & 26.3 & 0.52 & 0.20 & 0.713024 & 13 & 0.10 \\
\hline LZR-4 & $\begin{array}{l}20-06- \\
2007\end{array}$ & -8.19 & 146 & 21.5 & 40.1 & 39.3 & 309 & 114 & 0.51 & 5.22 & 1346 & 36.2 & 2.65 & 0.29 & 0.712454 & 12 & 0.27 \\
\hline LZR-5 & $\begin{array}{l}28-06- \\
2007\end{array}$ & -8.28 & 179 & 17.5 & 41.1 & 49.4 & 281 & 102 & 7.93 & 1.30 & 1718 & 74.9 & 3.30 & 0.76 & 0.711882 & 11 & 0.20 \\
\hline LZR-6 & $\begin{array}{l}04-07- \\
2007\end{array}$ & -8.10 & 217 & 39.9 & 49.1 & 278 & 846 & 210 & 13.6 & 14.3 & 1891 & 80.6 & 3.32 & 0.62 & 0.711686 & 9 & 0.55 \\
\hline LZR-7 & $\begin{array}{l}10-07- \\
2007\end{array}$ & -8.20 & 207 & 36.9 & 54.6 & 230 & 502 & 13.1 & 9.97 & 34.8 & 2055 & 90.5 & 4.18 & 0.84 & 0.711570 & 10 & 0.37 \\
\hline LZR-8 & $\begin{array}{l}11-07- \\
2007\end{array}$ & -8.18 & 123 & 8.32 & 14.4 & 21.6 & 143 & 77.6 & 0.77 & 9.57 & 1226 & 28.0 & 1.66 & 0.26 & 0.712358 & 11 & 0.14 \\
\hline LZR-9 & $\begin{array}{l}18-07- \\
2007\end{array}$ & -8.14 & 222 & 35.0 & 79.2 & 105 & 626 & 46.8 & 19.9 & 42.2 & 2185 & 99.5 & 23.7 & 0.80 & 0.711678 & 9 & 0.35 \\
\hline LZR-10 & $\begin{array}{l}31-07- \\
2007\end{array}$ & -7.41 & 161 & 41.2 & 81.8 & 316 & 801 & 14.0 & 20.7 & 67.4 & 1319 & 135 & 4.63 & 0.89 & 0.711003 & 12 & 0.80 \\
\hline LZR-11 & $\begin{array}{l}06-08- \\
2007\end{array}$ & -7.76 & 130 & 17.2 & 31.1 & 192 & 254 & 14.0 & 49.4 & 6.96 & 1264 & 49.4 & 5.56 & 0.39 & 0.710413 & 12 & 0.36 \\
\hline LZR-12 & $\begin{array}{l}08-08- \\
2007\end{array}$ & -7.44 & 29 & 5.11 & 9.84 & 80.4 & 74.2 & 15.0 & 3.01 & 12.2 & 268 & 72.4 & 2.50 & 0.08 & 0.710800 & 7 & 0.46 \\
\hline LZR-13 & $\begin{array}{l}26-08- \\
2007\end{array}$ & -7.59 & 81 & 19.9 & 30.2 & 96.0 & 245 & 16.8 & 7.16 & 16.1 & 721 & 47.7 & 4.13 & 0.42 & 0.710988 & 9 & 0.48 \\
\hline LZR-14 & $\begin{array}{l}29-08- \\
2007\end{array}$ & -7.72 & 105 & 22.7 & 29.4 & 50.6 & 325 & 153 & 8.18 & 0.87 & 867 & 23.0 & 0.46 & 0.03 & 0.710417 & 11 & 0.41 \\
\hline LZR-15 & $\begin{array}{l}30-08- \\
2007\end{array}$ & -7.12 & 30 & 6.58 & 9.11 & 62.4 & 84.6 & 99.1 & 1.02 & 8.70 & 255 & 12.3 & 0.44 & 0.00 & 0.710325 & 11 & 0.43 \\
\hline LZR-16 & $\begin{array}{l}12-09- \\
2007\end{array}$ & -7.76 & 257 & 76.8 & 437 & 346 & 1420 & 48.2 & 37.3 & 98.3 & 2132 & 170 & 7.35 & 0.87 & 0.710867 & 15 & 0.92 \\
\hline LZR-17 & $\begin{array}{l}17-09- \\
2007\end{array}$ & -7.81 & 90 & 12.6 & 24.7 & 47.2 & 147 & 14.0 & 5.37 & 4.78 & 930 & 41.1 & 7.63 & 0.26 & 0.711946 & 11 & 0.23 \\
\hline LZR-18 & $\begin{array}{l}27-09- \\
2007\end{array}$ & -7.37 & 52 & 4.89 & 16.1 & 56.6 & 67.4 & 48.6 & 2.05 & 2.17 & 159 & 20.6 & 8.45 & 0.05 & 0.710590 & 13 & 0.62 \\
\hline LZR-19 & $\begin{array}{l}01-10- \\
2007\end{array}$ & -6.82 & 15 & 7.79 & 14.8 & 16.3 & 84.1 & 64.5 & 1.53 & 4.61 & 115 & 16.5 & 3.23 & 0.05 & 0.71075 & 12 & 0.61 \\
\hline LZR-20 & $\begin{array}{l}03-10- \\
2007\end{array}$ & 7.12 & 67 & 18.5 & 22.8 & 35.2 & 280 & 153 & 4.35 & 3.91 & 463 & 16.5 & 2.76 & 0.14 & 0.710252 & 8 & 0.56 \\
\hline LZR-21 & $\begin{array}{l}05-10- \\
2007\end{array}$ & -7.83 & 84 & 9.11 & 11.7 & 17.2 & 120 & 154 & 6.14 & 0.87 & 651 & 29.6 & 6.32 & 0.18 & 0.711780 & 13 & 0.19 \\
\hline LZR-22 & $\begin{array}{l}08-10- \\
2007\end{array}$ & -8.23 & 107 & 19.2 & 23.9 & 42.6 & 284 & 146 & 4.86 & 2.17 & 894 & 28.0 & 13.0 & 0.24 & 0.711861 & 21 & 0.34 \\
\hline LZR-23 & $\begin{array}{l}11-10- \\
2007\end{array}$ & -8.19 & 103 & 14.6 & 17.6 & 31.3 & 214 & 150 & 5.12 & 3.48 & 844 & 28.8 & 13.8 & 0.24 & 0.711840 & 10 & 0.27 \\
\hline
\end{tabular}

$\Sigma_{\text {anions }} / \Sigma_{\text {cations }}=$ ratios of sum of anions to that of cations.

by the base cations. Furthermore, the temporal variation of $\mathrm{pH}$ and the content of $\mathrm{Ca}^{2+}$ and $\mathrm{Mg}^{2+}$ in Table 1 show high $\mathrm{pH}$ and ionic concentrations during the early period of the rainy season. This reflects a strong impact of alkaline soil dust on rainwater quality due to large inputs of soil dust in the atmosphere during the winter and spring in this area (Han et al., 2004).

\subsection{Sources of major ions}

Atmosphere aerosols including sea salts, crustal dust, biogenic material, and anthropogenic emissions are main sources of chemical compositions in rainwater (Roy and Negrel, 2001; Chetelat et al., 2005; Negrel et al., 2007). In order to estimate the presence of sea salt (ss) and non-seasalt (nss) in rainwater, sodium has typically been used as a reference element $\left(\mathrm{Na}_{\mathrm{ref}}\right)$. However, the choice of this element as a reference must be validated, particularly with regard to possible terrestrial influence. We, therefore, use the approach proposed by Negrel and Roy (1998). Assuming that aluminum is almost exclusively derived from non-sea-salt material input, the non-sea-salt $\mathrm{Na}\left(\mathrm{Na}_{\mathrm{nss}}\right)$ can be calculated as follows:

$\mathrm{Na}_{\mathrm{nss}}=\mathrm{Al}_{\mathrm{rw}} \times(\mathrm{Na} / \mathrm{Al})_{\mathrm{nss}}$

Hofmann et al. (1977) and Church et al. (1984) have shown that shale is more representative of average soil than rocks of the upper continental crust. Therefore, the correction of crustal $\mathrm{Na}$ with $\mathrm{Al}$ has been applied using shale as a terrestrial dust reference, and the $\mathrm{Na} / \mathrm{Al}$ ratio for shale is 0.11 
Table 2

Volume weighted mean concentrations of major ion (in $\mu \mathrm{eq} \mathrm{l}^{-1}$ ), $\mathrm{Al}$ and $\mathrm{Sr}$ (in $\mu \mathrm{mol} \mathrm{l}^{-1}$ ), and $\mathrm{pH}$ (in unit) along with statistical results in rainwaters.

\begin{tabular}{lllllll}
\hline Component & VWM & Median & Mean & S.D. & Min & Max \\
\hline $\mathrm{pH}$ & 7.70 & 7.83 & 7.82 & 0.43 & 6.82 & 8.28 \\
$\mathrm{EC}$ & 95.7 & 119 & 124 & 67.3 & 15.0 & 257 \\
$\mathrm{~F}^{-}$ & 13.6 & 17.5 & 20.9 & 16.9 & 4.32 & 76.8 \\
$\mathrm{Cl}^{-}$ & 27.9 & 24.7 & 48.3 & 87.4 & 6.52 & 437 \\
$\mathrm{NO}_{3}^{-}$ & 74.4 & 50.6 & 102 & 105 & 5.0 & 346 \\
$\mathrm{SO}_{4}^{2-}$ & 208 & 254 & 340 & 328 & 48.1 & 1420 \\
$\mathrm{NH}_{4}^{+}$ & 57.2 & 65.5 & 78.8 & 59.1 & 13.1 & 210 \\
$\mathrm{~K}^{+}$ & 7.26 & 6.14 & 10.1 & 12.1 & 0.51 & 49.4 \\
$\mathrm{Na}^{+}$ & 12.3 & 6.96 & 16.5 & 24.1 & 0.87 & 98.3 \\
$\mathrm{Ca}^{2+}$ & 886 & 1222 & 1124 & 659 & 115 & 2185 \\
$\mathrm{Mg}^{2+}$ & 46.5 & 36.2 & 54.5 & 41.7 & 12.3 & 170 \\
$\mathrm{Al}$ & 3.35 & 3.32 & 5.25 & 5.47 & 0.44 & 23.7 \\
$\mathrm{Sr}$ & 0.28 & 0.26 & 0.38 & 0.31 & 0.004 & 0.89 \\
\hline
\end{tabular}

$\mathrm{VWM}=$ volume-weighted mean; S.D. = standard deviation; $\mathrm{Min}=$ minimum; Max $=$ maximum

(Negrel and Roy, 1998). We can thus correct the measured Na in rainwater $\left(\mathrm{Na}_{\mathrm{rw}}\right)$ for a non-sea-salt contribution:

$\mathrm{Na}_{\mathrm{ref}}=\mathrm{Na}_{\mathrm{rw}}-0.11 \times \mathrm{Al}_{\mathrm{rw}}$

where $\mathrm{Al}_{\mathrm{rw}}$ is the concentration measured in rainwater. The contribution of non-sea-salt components for a given element $X\left(X=\mathrm{K}^{+}, \mathrm{Ca}^{2+}, \mathrm{Mg}^{2+}, \mathrm{Sr}^{2+}\right.$, and $\left.\mathrm{SO}_{4}^{2-}\right)$ is thus calculated:

$X_{\mathrm{nss}}=X_{\mathrm{rw}}-\mathrm{Na}_{\mathrm{ref}} \times(X / \mathrm{Na})_{\mathrm{sw}}$

where $(X / \mathrm{Na})_{\text {sw }}$ is the elemental ratios of seawater; elemental ratios $(X / \mathrm{Na})_{\text {sw }}$ are determined according to the composition of sea water given by Berner and Berner (1987). All equations mentioned are expressed on a molar basis. The results, expressed in percentage, are shown in Table 5 and indicate that the chemical composition of rainwater has a typical continental characteristic in Lanzhou. $\mathrm{Ca}^{2+}$ is generally a dominant alkaline cation in precipitation, and thus, of importance to neutralizing acidity of rain (Nakano and Tanaka, 1997; Larssen and Carmichael, 2000). The $\mathrm{Ca}^{2+}$ in rainwater from Lanzhou is mainly of non-sea-salt origin; marine $\mathrm{Ca}^{2+}$ proportions are very low for the whole data set (Table 5 ). Numerous sources, both local and remote, of natural inputs (soil dust) and anthropogenic pollution (municipal constructions, cement factories, and/or coal combustion, etc.) must be considered. One of the non-sea-salt components can possibly be related to calcic particles from local and remote soil dust. As shown in Fig. 1, Lanzhou is located on the Loess Plateau and surrounded by several desert areas. Most importantly, calcification and salinization are dominant soil formation processes in these arid and semi-arid regions. The soil in the loess and desert areas, a great source of region's soil dust in the atmosphere, is commonly rich in carbonate and evaporite and sulfate minerals (calcite, gypsum, halite, bloedite, etc.) (Okuda et al., 1992; Zhang et al., 1995, 2003b). The apparent correlations among ions $\left(\mathrm{K}^{+}, \mathrm{Na}^{+}, \mathrm{Ca}^{2+}, \mathrm{Mg}^{2+}, \mathrm{SO}_{4}^{2-}\right.$, etc.) indicate that these elements have a common source (Table 4). Therefore, we suggest that these ions in rainwater, especially the high content of $\mathrm{Ca}^{2+}$ and $\mathrm{Mg}^{2+}$, are mainly due to the contribution of natural soil dust. Another source of these elements is probably anthropogenic pollution (industrial and/or agricultural activities). However, we cannot precisely characterize the different endmembers merely by means of major element composition. Therefore, the $\mathrm{Sr}$ isotope is used to obtain additional information of the different possible non-sea-salt sources in the next section of this paper.

Besides the contribution of sulfate minerals $\left(\mathrm{CaSO}_{4}\right.$ and $\mathrm{MgSO}_{4}$ ) in soil dust, non-sea-salt $\mathrm{SO}_{4}^{2-}$ may also originate from anthropogenic emissions of $\mathrm{SO}_{2}$. Coal combustion accounts for about $70 \%$ of the commercial energy production in China, leading to large amounts of $\mathrm{SO}_{2}$ emissions, which to date has been the most important precursor of acid rain in

Table 3

Comparison of the major ion concentrations (in $\mu \mathrm{eq}^{-1}$ ) and $\mathrm{pH}$ values in Lanzhou with other sites in China and worldwide.

\begin{tabular}{|c|c|c|c|c|c|c|c|c|c|c|}
\hline Site & $\mathrm{pH}$ & $\mathrm{F}^{-}$ & $\mathrm{Cl}^{-}$ & $\mathrm{NO}_{3}^{-}$ & $\mathrm{SO}_{4}^{2-}$ & $\mathrm{NH}_{4}^{+}$ & $\mathrm{K}^{+}$ & $\mathrm{Na}^{+}$ & $\mathrm{Ca}^{2+}$ & $\mathrm{Mg}^{2+}$ \\
\hline This study & 7.70 & 13.6 & 27.9 & 74.4 & 208 & 57.2 & 7.26 & 12.3 & 886 & 46.5 \\
\hline Lhasa $^{a}$ & 7.50 & 0.40 & 9.70 & 6.90 & 5.20 & 14.3 & 5.14 & 11.2 & 197 & 10.9 \\
\hline Nam Co ${ }^{b}$ & 6.59 & & 19.2 & 10.4 & 15.5 & 18.1 & 14.5 & 15.4 & 65.6 & 7.43 \\
\hline Qinghai $^{c}$ & 7.1 & 46.6 & 48.8 & 48.1 & 84.0 & 161 & 69.2 & 96.6 & 314 & 37.9 \\
\hline Beijing $^{d}$ & 5.12 & 15.7 & 104 & 109 & 316 & 186 & 17.7 & 25.0 & 607 & 40.4 \\
\hline Shanghai ${ }^{\mathrm{e}}$ & 4.49 & 11.0 & 58.3 & 49.8 & 200 & 80.7 & 14.9 & 50.1 & 204 & 29.6 \\
\hline Nanjing ${ }^{f}$ & 5.51 & & 143 & 39.6 & 242 & 193 & 12.1 & 23.0 & 295 & 31.7 \\
\hline Ankara (Turkey) ${ }^{g}$ & 6.3 & & 20.4 & 29.2 & 48 & 86.4 & 9.8 & 15.6 & 71.4 & 9.3 \\
\hline Lucknow (India) $^{\mathrm{h}}$ & 6.5 & 4.6 & 9.9 & 7.66 & 9.27 & 3.57 & 2.42 & 8.45 & 14.9 & 4.44 \\
\hline Petra (Jordan) ${ }^{\mathrm{i}}$ & 6.85 & & 80.6 & 35.7 & 53.2 & 26.3 & 18.4 & 75.6 & 163 & 62.3 \\
\hline Ahmedabad (India) ${ }^{\mathrm{j}}$ & 6.7 & & 50 & 13 & 37 & 30 & 3.4 & 41 & 78 & 15 \\
\hline Tirupati (India) ${ }^{\mathrm{k}}$ & 6.78 & 4.72 & 33.9 & 40.8 & 128 & 20.4 & 33.9 & 33.1 & 151 & 55.5 \\
\hline
\end{tabular}

a Zhang et al. (2003b).

b Li et al. (2007).

c Zhang et al. (2003a).

d Xu and Han (2002).

e Huang et al. (2008).

f Tu et al. (2005)

g Topcu et al. (2002).

h Khare et al. (2004).

i Al-Khashman (2005).

j Rastogi and Sarin (2005).

k Mouli et al. (2005). 
Table 4

Correlation coefficients between major components for rainwaters from Lanzhou, significance of correlation: $p<0.05$.

\begin{tabular}{|c|c|c|c|c|c|c|c|c|c|c|}
\hline & $\mathrm{F}^{-}$ & $\mathrm{Cl}^{-}$ & $\mathrm{NO}_{3}^{-}$ & $\mathrm{SO}_{4}^{2-}$ & $\mathrm{NH}_{4}^{+}$ & $\mathrm{K}^{+}$ & $\mathrm{Na}^{+}$ & $\mathrm{Ca}^{2+}$ & $\mathrm{Mg}^{2+}$ & $\mathrm{OH}^{-}$ \\
\hline $\mathrm{F}^{-}$ & 1 & & & & & & & & & \\
\hline $\mathrm{Cl}^{-}$ & 0.86 & 1 & & & & & & & & \\
\hline $\mathrm{NO}_{3}^{-}$ & 0.85 & 0.65 & 1 & & & & & & & \\
\hline $\mathrm{SO}_{4}^{2-}$ & 0.99 & 0.85 & 0.87 & 1 & & & & & & \\
\hline $\mathrm{NH}_{4}^{+}$ & -0.07 & -0.16 & -0.27 & -0.02 & 1 & & & & & \\
\hline $\mathrm{K}^{+}$ & 0.62 & 0.58 & 0.70 & 0.62 & -0.31 & 1 & & & & \\
\hline $\mathrm{Na}^{+}$ & 0.87 & 0.85 & 0.81 & 0.87 & -0.39 & 0.58 & 1 & & & \\
\hline $\mathrm{Ca}^{2+}$ & 0.72 & 0.49 & 0.61 & 0.70 & -0.12 & 0.50 & 0.56 & 1 & & \\
\hline $\mathrm{Mg}^{2+}$ & 0.87 & 0.75 & 0.87 & 0.88 & -0.38 & 0.62 & 0.91 & 0.70 & 1 & \\
\hline $\mathrm{OH}^{-}$ & 0.04 & -0.08 & -0.12 & 0.02 & 0.20 & -0.11 & -0.12 & 0.60 & 0.04 & 1 \\
\hline
\end{tabular}

Statistically significant coefficients are indicated in bold.

China (Aas et al., 2007). Lanzhou is one of the most important industrial cities in China, with its oil refineries and chemical and metallurgical industries ranked highest in China. Therefore, the emissions of $\mathrm{SO}_{2}$ from fossil fuel combustion would be another important source of $\mathrm{SO}_{4}^{2-}$ in rainwater. $\mathrm{NO}_{3}^{-}$in rainwater emanates from both human activities (like fuel combustion) and chemical reactions in the atmosphere. Coal combustion certainly produces large amounts of $\mathrm{NO}_{x}$. A highly positive correlation between $\mathrm{SO}_{4}^{2-}$ and $\mathrm{NO}_{3}^{-}(r=0.87)$ indicates that they are from similar sources, and reflects the input of pollutants from fossil fuel combustion in the Lanzhou region.

In addition, the precipitation we studied is significantly rich in $\mathrm{Cl}^{-}$and high $\mathrm{Cl} / \mathrm{Na}$ molar ratios, with an average value of 6.66. The $\mathrm{Cl} / \mathrm{Na}$ ratio of the rainwater is several times higher than that of seawater $(\mathrm{Cl} / \mathrm{Na}=1.17$, Berner and Berner, 1987), indicating that significant non-sea-salt $\mathrm{Cl}$ sources exist. The non-sea-salt $\mathrm{Cl}^{-}$may be derived from natural sources, for example, the dissolution of evaporite minerals (halite, sylvite) from soil dust. However, the $\mathrm{Cl} /(\mathrm{Na}+\mathrm{K})$ ratio of most samples is still higher than 1 , suggesting the presence of anthropogenic

Table 5

Proportions (in \%) of the non-sea-salt contribution in the rainwaters.

\begin{tabular}{lllllll}
\hline Sample & $\mathrm{K}^{+}$ & $\begin{array}{l}\mathrm{Na}^{+} \\
\text {number }\end{array}$ & $\begin{array}{l}\mathrm{Ca}^{2+} \\
(\%)\end{array}$ & $\begin{array}{l}\mathrm{Mg}^{2+} \\
(\%)\end{array}$ & $\begin{array}{l}\mathrm{Sr}^{2+} \\
(\%)\end{array}$ & $\begin{array}{l}\mathrm{SO}_{4}^{2-} \\
(\%)\end{array}$ \\
\hline LZR-1 & 95.72 & 0.30 & 99.94 & 93.39 & 99.35 & 99.38 \\
LZR-2 & 99.47 & 2.92 & 99.99 & 98.61 & 99.86 & 99.58 \\
LZR-3 & 80.62 & 0.63 & 99.97 & 92.19 & 99.15 & 98.96 \\
LZR-4 & 78.96 & 5.59 & 99.98 & 96.92 & 99.68 & 99.81 \\
LZR-5 & 99.74 & 27.9 & 100 & 99.72 & 99.98 & 99.96 \\
LZR-6 & 97.75 & 2.54 & 99.97 & 96.07 & 99.57 & 99.80 \\
LZR-7 & 92.48 & 1.32 & 99.93 & 91.40 & 99.22 & 99.19 \\
LZR-8 & 73.28 & 1.91 & 99.97 & 92.40 & 99.30 & 99.22 \\
LZR-9 & 95.67 & 6.17 & 99.92 & 90.99 & 99.05 & 99.25 \\
LZR-10 & 92.95 & 0.76 & 99.78 & 88.77 & 98.55 & 99.01 \\
LZR-11 & 99.72 & 8.80 & 99.98 & 97.09 & 99.69 & 99.70 \\
LZR-12 & 91.37 & 2.26 & 99.81 & 96.27 & 97.00 & 98.10 \\
LZR-13 & 95.23 & 2.83 & 99.90 & 92.57 & 99.29 & 99.24 \\
LZR-14 & 99.78 & 5.85 & 100 & 99.19 & 99.46 & 99.97 \\
LZR-15 & 81.53 & 0.56 & 99.85 & 84.12 & 54.15 & 98.79 \\
LZR-16 & 94.30 & 0.82 & 99.80 & 87.03 & 97.86 & 99.19 \\
LZR-17 & 98.40 & 17.6 & 99.98 & 97.83 & 99.70 & 99.68 \\
LZR-18 & 98.67 & 42.7 & 99.97 & 98.63 & 99.50 & 99.78 \\
LZR-19 & 93.94 & 7.71 & 99.84 & 94.14 & 98.28 & 99.40 \\
LZR-20 & 98.19 & 7.77 & 99.97 & 95.03 & 99.50 & 99.85 \\
LZR-21 & 99.94 & 80.0 & 100 & 99.87 & 99.98 & 99.98 \\
LZR-22 & 99.66 & 65.6 & 100 & 99.39 & 99.94 & 99.97 \\
LZR-23 & 99.16 & 43.6 & 99.99 & 98.46 & 99.84 & 99.89 \\
\hline
\end{tabular}

sources of $\mathrm{Cl}^{-}$. Given that Lanzhou is one of the most important industrial cities in China and the sampling site is located in the central part of the city, therefore, the $\mathrm{Cl}^{-}$could be derived from anthropogenic inputs, such as coal combustion, the chemical industry, and automobile exhaust fumes. $\mathrm{Cl}^{-}$input from the pollutant sources can also be further proven by positive correlations between $\mathrm{SO}_{4}^{2-}, \mathrm{NO}_{3}^{-}$and $\mathrm{Cl}^{-}$(Table 4).

From the data set in Table 3 , it can be seen that the concentration of $\mathrm{F}^{-}$in rainwater from Lanzhou and other sites of China is higher than that from other sites worldwide. Fluorine is one of the most toxic and volatilized elements present in coal. During combustion, it is emitted as $\mathrm{HF}, \mathrm{SiF}_{4}$, and $\mathrm{CF}_{4}$ (Liu et al., 2006). Therefore, coal combustion has been identified as an important source of $\mathrm{F}$ emissions. Luo et al. (2002) measured the annual coal consumption in China for power plants and domestic heating at about $8 \times 10^{9} \mathrm{t}$. If the lower range of the $\mathrm{F}$ concentrations $\left(100 \mathrm{~g} \mathrm{t}^{-1}\right)$ in coal is used, the atmosphere contains about 66,000 $\mathrm{t}$ of $\mathrm{F}$, more than twice that of the U.S. (Liu et al., 2006). The highest correlation between $\mathrm{F}^{-}$and $\mathrm{SO}_{4}^{2-}(r=0.99)$ and relatively high correlations with other ions $\left(\mathrm{Cl}^{-}, \mathrm{NO}_{3}^{-}, \mathrm{Ca}^{2+}, \mathrm{Mg}^{2+}\right)$ in this work (Table 4) indicate the common sources of these elements as fly ash and flue gases of coal burning in power plants and domestic heating (Brueggemann and Rolle, 1998).

\subsection{Strontium isotope constraints}

From our discussions above, acid rain has not been recorded in Lanzhou despite large emissions of acidic pollutants, whose neutralization is attributed to the presence of base cations (mainly $\mathrm{Ca}^{2+}$ ). Identifying the provenance of $\mathrm{Ca}$ in precipitation is of special importance because this element is a dominant cation which neutralizes acidity of rainwater and indispensable for plant growth (Hedin and Likens, 1996; Schmitt and Stille, 2005). Strontium acts as a proxy for Ca because both are alkaline earth elements with similar ionic radii and the same valences (Capo et al., 1998), and similar geochemical behaviors (Åberg, 1995; Nakano et al., 2006). For these reasons, the ${ }^{87} \mathrm{Sr} /{ }^{86} \mathrm{Sr}$ isotopic ratio of natural materials can be used to identify and to quantify the contribution of different $\mathrm{Sr}$ sources (and, by inference, of $\mathrm{Ca}$ ) in precipitation. Furthermore, strontium is a high-mass element; therefore, isotopic fractionation from geologic and biological processes is very small compared to that in low-mass isotopic systems (e.g. $\delta^{18} \mathrm{O}, \delta^{2} \mathrm{H}$ ). Moreover, massdependent fractionation of $\mathrm{Sr}$ isotopes (whether natural or instrument-induced) is corrected for during mass spectrometric measurement by normalization of the non-radiogenic isotopes to 
known values. Therefore, the measured ${ }^{87} \mathrm{Sr} /{ }^{86} \mathrm{Sr}$ isotopic ratio reflects only variations in the amount of radiogenic ${ }^{87} \mathrm{Sr}$ present in the sample, which is a function of its source. The net result is that the strontium isotopic compositions of a sample yields information about provenance or geologic interactions (Capo et al., 1998).

Several researchers have reported $\mathrm{Sr}$ concentrations and ${ }^{87} \mathrm{Sr} /$ ${ }^{86} \mathrm{Sr}$ isotopic ratios in rainwater and their results have highlighted the role of aerosol sources in the isotopic signature of rain (Herut et al., 1993; Nakano and Tanaka, 1997; Negrel and Roy, 1998; Schmitt and Stille, 2005; Chabaux et al., 2005; Han and Liu, 2006; Negrel et al., 2007). Soil dust originating from loess and desert areas in China, generally termed Kosa, is considered to be a major source of non-sea-salt $\mathrm{Ca}$, which plays an important role in the chemical composition and acidity of precipitation in northeastern Asia (Nakano and Tanaka, 1997; Fujita et al., 2000; Yokoo et al., 2001; Kanayama et al., 2002; Nakano et al., 2006). However, the chemical and $\mathrm{Sr}$ isotopic characteristics of rainwater in the Loess Plateau region, where loess soils and desert sands cover vast areas in the arid and semi-arid regions of northwest China, has not been reported in literature.

The $\mathrm{Sr}$ concentrations of rainwater in Lanzhou show a range of 0.004 to $0.885 \mu \mathrm{mol} 1^{-1}$, whereas ${ }^{87} \mathrm{Sr} /{ }^{86} \mathrm{Sr}$ ratios span a range of 0.71025 to 0.71302 , with an average value of 0.71143 . The ${ }^{87} \mathrm{Sr} /{ }^{86} \mathrm{Sr}$ ratios of all rainwater samples are higher than that of seawater (0.70917, Dia et al., 1992), which reflects a contribution from at least one radiogenic Sr source. The most suitable candidate would be the input of soil dust from local and distant continental bedrock and soil, which are obviously more radiogenic. Furthermore, from the data in Table 1 and Fig. 2, an obvious feature can be observed where the rain events with higher $\mathrm{pH}, \mathrm{Ca}$ and $\mathrm{Sr}$ content as well as ${ }^{87} \mathrm{Sr} /{ }^{86} \mathrm{Sr}$ ratio most frequently occur during the early period of the rainy season and tend to decrease from the beginning toward the end of the rainy season. The temporal variation of the $\mathrm{pH}, \mathrm{Ca}$ and $\mathrm{Sr}$ content and ${ }^{87} \mathrm{Sr} /{ }^{86} \mathrm{Sr}$ ratio reflects a significant impact of the input of soil dust in the atmosphere on the chemical and isotopic signature of rainwater at the early period of the rainy season in this region.

The ${ }^{87} \mathrm{Sr} /{ }^{86} \mathrm{Sr}$ composition of soil dust can be estimated by studying the ${ }^{87} \mathrm{Sr} /{ }^{86} \mathrm{Sr}$ ratio of river waters and leaching experiment of soils in this region. Zhang et al. (1995) reported ${ }^{87} \mathrm{Sr} /{ }^{86} \mathrm{Sr}$ ratios of $0.7111-0.7154$ from rivers around the Taklimakan Desert in northwest China. The Huanghe (Yellow River) also has a similar ${ }^{87} \mathrm{Sr} /{ }^{86} \mathrm{Sr}$ ratio (0.7111; Parmer and Edmond, 1989). Liu et al. (1999) determined the
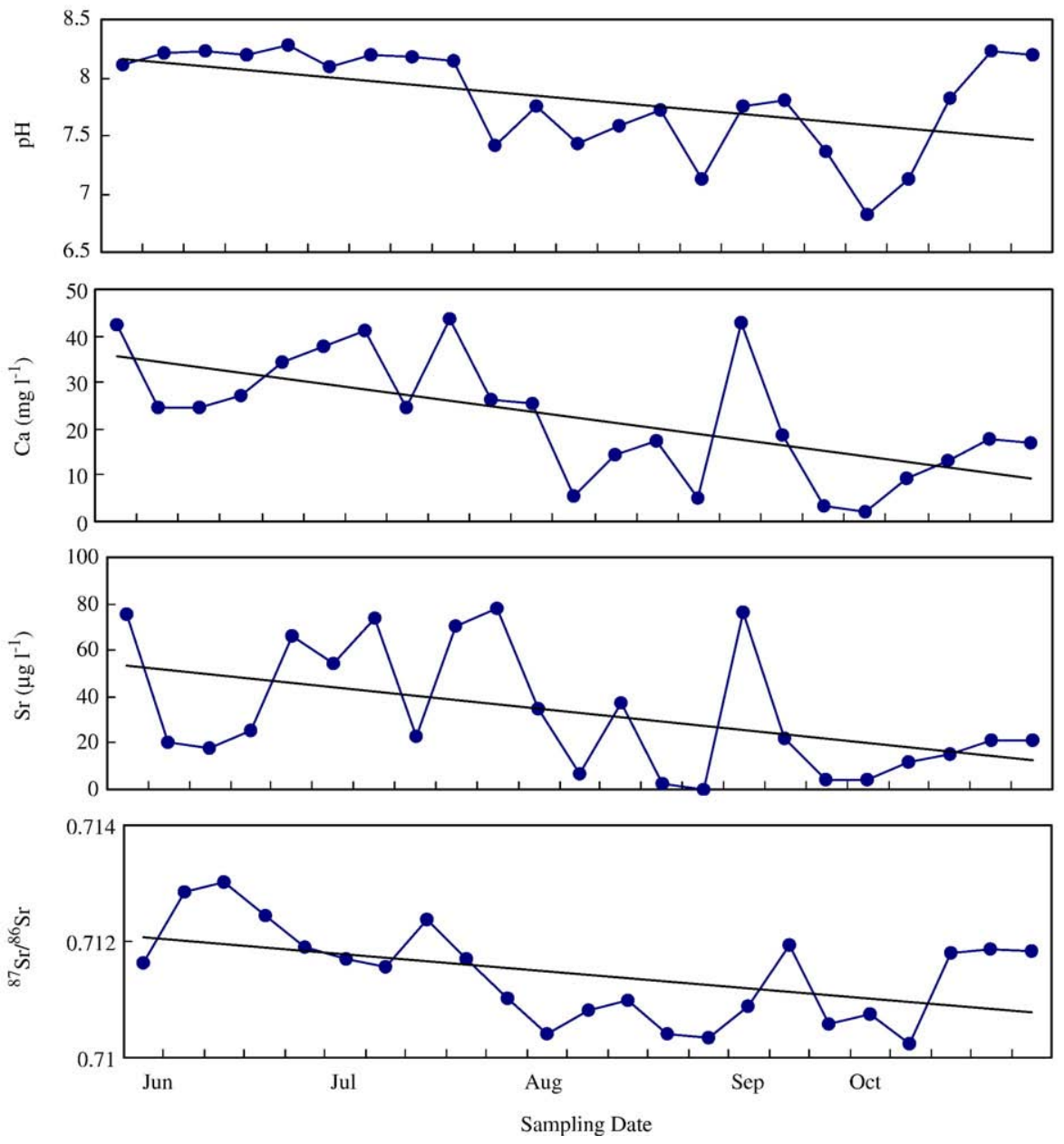

Fig. 2. The temporal variation of the $\mathrm{pH}, \mathrm{Ca}$ and $\mathrm{Sr}$ content, and $\mathrm{Sr}$ isotopic ratio of the rainwater in Lanzhou. 
Sr isotopic composition of carbonate $\left({ }^{87} \mathrm{Sr} /{ }^{86} \mathrm{Sr}=0.7104\right.$ 0.7120 ) in the Heimugou loess-paleosol section in Luochuan of Shannxi Province. Yokoo et al. (2004) further determined the ${ }^{87} \mathrm{Sr} /{ }^{86} \mathrm{Sr}$ composition of minerals in loess and desert sand from the central Loess Plateau: the loess exhibits a narrow range of variation in ${ }^{87} \mathrm{Sr} /{ }^{86} \mathrm{Sr}=0.715 \pm 0.001$. Leaching experiments on the loess and sands reveal water- and HOAcsoluble minerals, $\mathrm{HCl}$-soluble minerals, and $\mathrm{HCl}$-insoluble minerals have ${ }^{87} \mathrm{Sr} /{ }^{86} \mathrm{Sr}$ ratios of approximately $0.7111 \pm$ $0.0004,0.7141 \pm 0.0004$, and $0.7195 \pm 0.0010$, respectively. The ${ }^{87} \mathrm{Sr} /{ }^{86} \mathrm{Sr}$ ratios $(0.71025 \sim 0.71302$, an average of 0.71143 ) of Lanzhou rainwater in this study are consistent with previous studies of water- and weak-acid-soluble minerals in the surface soils in the arid region of northern China (0.7095-0.7130, an average of 0.7115, Nakano et al., 2004), and data of water- and HOAc-soluble minerals in loess and desert sands from the central Loess Plateau (0.71070.7128 , an average of $0.7111 \pm 0.0004$, Yokoo et al., 2004). Accordingly, the high ${ }^{87} \mathrm{Sr} /{ }^{86} \mathrm{Sr}$, Ca and $\mathrm{Sr}$ content in the rainwater from Lanzhou can all be attributed to the dissolution of calcium carbonate in soil dust. We adopt the maximum ${ }^{87} \mathrm{Sr} /{ }^{86} \mathrm{Sr}$ isotopic ratio of 0.7130 as the natural soil dust end-member for the rainwater in Lanzhou.

The plots of ${ }^{87} \mathrm{Sr} /{ }^{86} \mathrm{Sr}$ vs. Ca/Sr and K/Sr molar ratio (Fig. 3a and b) suggest that most of the samples from Lanzhou can be interpreted in terms of mixing between two end-members: soil dust from the Loess Plateau and deserts in northwest China (with ${ }^{87} \mathrm{Sr} /{ }^{86} \mathrm{Sr}$ about 0.7130 ), and seawater (with ${ }^{87} \mathrm{Sr} /$ $\left.{ }^{86} \mathrm{Sr}=0.70917\right)$. However, two samples (LZR-14 and LZR-15), with ${ }^{87} \mathrm{Sr} /{ }^{86} \mathrm{Sr}$ ratio $(\sim 0.7103)$ and very high $\mathrm{Ca} / \mathrm{Sr}$ and $\mathrm{K} / \mathrm{Sr}$
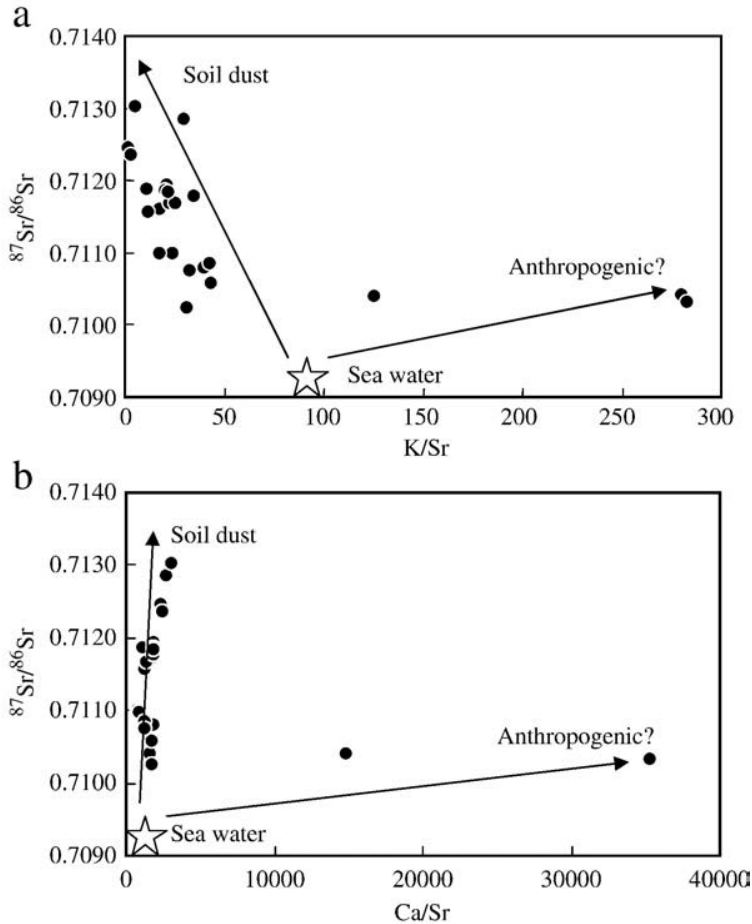

Fig. 3. Variation of $\mathrm{Sr}$ isotopic ratio against $\mathrm{K} / \mathrm{Sr}$ (a) and $\mathrm{Ca} / \mathrm{Sr}$ (b) molar ratio of the rainwater in Lanzhou. The characteristic values of soil dust and anthropogenic inputs are discussed in the test for detail. ratios, cannot be attributed to the mixing of seawater and soil dust end-members (Fig. 3a and b). These data indicate that, except soil-dust, the Lanzhou rainwater contains another nonsea-salt source, probably of a natural or anthropogenic input. Nakano and co-workers concluded that plant-derived $\mathrm{Sr}$ is contained in rainwater in several mountainous areas of Japan extensively covered with vegetation (Nakano and Tanaka, 1997; Nakano et al., 2000, 2001, 2006). Lanzhou is located on the Loess Plateau in the arid and semi-arid areas of northwest China, where vegetation is lacking. Consequently, a plant component is unlikely to be a source of the non-sea-salt Ca and $\mathrm{Sr}$ in precipitation. The second non-sea-salt end-member is probably of an anthropogenic input. Since the Sr isotope ratios of typical contaminant sources for the rainwater collected in Lanzhou have not been characterized, we can only refer such values from literature. Fertilizers usually possess high $\mathrm{Sr}$ concentrations of up to $1500 \mathrm{ppm}$ and low ${ }^{87} \mathrm{Sr} /{ }^{86} \mathrm{Sr}$ ratios ranging between 0.7079 and 0.7087 (Negrel and Deschamps, 1996; Negrel and Roy, 1998; Negrel et al., 2007). Thus, agricultural activities would not be a source of the non-sea-salt $\mathrm{Ca}$ and $\mathrm{Sr}$ in the precipitation in Lanzhou.

It is obvious that the second non-sea-salt end-members have a low $\mathrm{Sr}$ content and relatively high $\mathrm{Ca}$ and $\mathrm{K}$ content; the $\mathrm{Ca} / \mathrm{Sr}$ ratio is higher than that of carbonate minerals from desert sands and loess soils in China, ranging between 250 and 1000 (Yokoo et al., 2004; Nakano et al., 2006). This indicates that the very high $\mathrm{Ca} / \mathrm{Sr}$ ratio of Lanzhou rainwater is not caused by Ca-rich soil dust from the arid and semi-arid regions in northwest China. If anything, it is probable that anthropogenic Ca-abundant aerosols are dissolved in the rainwater in Lanzhou City. The anthropogenic Ca-abundant particles in atmospheric aerosols, such as construction materials, were previously reported in Beijing aerosols by Zhang and Iwasaka (1999). Kanayama et al. (2002) suggested that the Ca-abundant urban aerosols are more affected by anthropogenic sources, such as road deposits or asphalts, and have an ${ }^{87} \mathrm{Sr} /{ }^{86} \mathrm{Sr}$ ratio about 0.709 . Recent data obtained in the Parisian atmosphere (Negrel et al., 2007) indicate that an ${ }^{87} \mathrm{Sr} /{ }^{86} \mathrm{Sr}$ ratio ranges between 0.7083 and 0.73335 for urban heating, and between 0.7097 and 0.7100 for incinerators. Though it is difficult to identify the sources for the anthropogenic inputs based on these data, it can at least be suggested that the anthropogenic end-member for Lanzhou rainwater would be characterized by ${ }^{87} \mathrm{Sr} /{ }^{86} \mathrm{Sr}$ with ratio about 0.7103 , low $\mathrm{Sr}$ content, and high $\mathrm{K} / \mathrm{Sr}$ and $\mathrm{Ca} / \mathrm{Sr}$ ratios.

Based on the observed isotopic characteristics of the rainwater from Lanzhou, the ${ }^{87} \mathrm{Sr} /{ }^{86} \mathrm{Sr}$ ratios are higher than that of seawater which indicates radiogenic $\mathrm{Sr}$ sources of aerosols. Additionally, as illustrated in Fig. 3, the data points congregate mainly toward the soil dust end-member. Therefore, the most important origin of the aerosols would be the soil dust transported from the local or remote desert and loess areas in northwest China. Anthropogenic inputs certainly cannot be entirely eliminated in Lanzhou.

\section{Conclusion}

The chemical and $\mathrm{Sr}$ isotopic compositions of rainwater were determined in Lanzhou City in northwest China over the rainy season in 2007. Lanzhou is one of the most polluted cities in the north of China. The rainwater samples in Lanzhou 
possess relatively high concentrations of acidic ions $\mathrm{SO}_{4}^{2-}$ and $\mathrm{NO}_{3}^{-}$) comparing with other sites in the world. However, the rainwater observed in this study was alkaline, with measured $\mathrm{pH}$ values ranging from 6.82 to 8.28 and a VWM pH of 7.70. This is mainly attributed to the neutralization of the acidity of rain by the high concentrations of alkaline ions (mainly $\mathrm{Ca}^{2+}$ ) derived from the soil dust. The variations of both chemical composition and the $\mathrm{Sr}$ isotopic signature reflect a significant influence of the soil dust in the atmosphere at the early and the late periods of the rainy season in this region.

The Sr concentrations vary from 0.004 to $0.885 \mu \mathrm{mol} \mathrm{l}^{-1}$, whereas ${ }^{87} \mathrm{Sr} /{ }^{86} \mathrm{Sr}$ ratios span a range of 0.71025 to 0.71302 , with an average value of 0.71143 in the rainwater samples; all samples show ${ }^{87} \mathrm{Sr} /{ }^{86} \mathrm{Sr}$ ratios are higher than that of sea water. We attempt to identify the origins of elements by using a combination of statistical analyses methods and $\mathrm{Sr}$ isotope systematics. The results suggest that the precipitation in this region has a typical continental characteristic. Covariation of the ${ }^{87} \mathrm{Sr} /{ }^{86} \mathrm{Sr}$ ratio with the related element ratios in the rainwater would suggest the presence of at least three sources of $\mathrm{Sr}$ in the rainwater, they are soil dust originating from the desert and loess areas (with ${ }^{87} \mathrm{Sr} /{ }^{86} \mathrm{Sr} \sim 0.7130$ ), sea salts or evaporites (with ${ }^{87} \mathrm{Sr} /{ }^{86} \mathrm{Sr}=0.70917$ ), and anthropogenic inputs (with ${ }^{87} \mathrm{Sr} /{ }^{86} \mathrm{Sr} \sim 0.7103$ and high $\mathrm{K} / \mathrm{Sr}$ and $\mathrm{Ca} / \mathrm{Sr}$ ratios). The use of strontium isotope analysis facilitates the interpretation of the chemical characterization of rainwater, and highlights the origins of the aerosols and the probable influence of the anthropogenic sources in the studied area.

\section{Acknowledgments}

This work was supported jointly by the Innovation Program of the Chinese Academy of Sciences (No. KZCX2-YW-205) and the Chinese National Natural Science Foundation (No. 40503017 and No. 40773077). We thank Hongsheng Xu (Lanzhou Institute of Geology, CAS) for sampling assistance. We also thank comments and suggestions from the editor-in-chief A. Flossmann and associate editor, and two anonymous reviewers.

\section{References}

Aas, W., Shao, M., Jin, L., Larssen, T., Zhao, D., Xiang, R., Zhang, J., Xiao, J., Duan, L., 2007. Air concentrations and wet deposition of major inorganic ions at five non-urban sites in China, 2001-2003. Atmospheric Environment 41, 1706-1716.

Åberg, G., 1995. The use of natural strontium isotopes as tracers in environmental studies. Water, Air, and Soil Pollution 79, 309-322.

Al-Khashman, O.A., 2005. Ionic composition of wet precipitation in the Petra Region, Jordan. Atmospheric Research 78, 1-12.

Andersson, P., Lofvendahl, R., Åberg, G., 1990. Major element chemistry, $\delta^{2} \mathrm{H}, \delta^{18} \mathrm{O}$ and ${ }^{87} \mathrm{Sr} /{ }^{86} \mathrm{Sr}$ in a snow profile across central Scandinavia. Atmospheric Environment 24A, 2601-2608.

Avila, A., 1996. Time trends in the precipitation chemistry at a mountain site in northeastern Spain for the period 1983-1994. Atmospheric Environment 30, 1363-1373.

Berner, E.K., Berner, R.A., 1987. The Global Water Cycle. Geochemistry and Environment. Prentice-Hall, New York.

Brueggemann, E., Rolle, W., 1998. Changes of some components of precipitation in East Germany after the unification. Water, Air, and Soil Pollution 107, 1-23.

Capo, R.C., Stewart, B.W., Chadwick, O.A., 1998. Strontium isotopes as tracers of ecosystem processes: theory and methods. Geodrama 82, 197-225.

Chabaux, F., Riotte, J., Schmitt, A.-D., Carignan, J., Herckes, P., Pierret, M.-C., Wortham, H., 2005. Variations of $\mathrm{U}$ and $\mathrm{Sr}$ isotope ratios in Alsace and Luxembourg rain waters: origin and hydrogeochemical implications. Comptes Rendus Geosciences 337, 1447-1456.
Charlson, R.J., Rodhe, H., 1982. Factors controlling the acidity of natural rainwater. Nature 295, 683-685.

Chetelat, B., Gaillardet, J., Freydier, R., Negrel, P., 2005. Boron isotopes in precipitation: experimental constraints and field evidence from French Guiana. Earth and Planetary Science Letters 235, 16-30.

Church, T.M., Tramontano, J.M., Sculdark, J.R., Jickells, T.D., Tokos, J.J., Knap, A.H., 1984. The wet deposition of trace metals to the western Atlantic ocean at the mid-Atlantic coast and on Bermuda. Atmospheric Environment 18, 2657-2664.

Dia, A.N., Cohen, A.S., O'Nions, R.K., Shackleton, N.J., 1992. Seawater Sr isotope variation over the past $300 \mathrm{kyr}$ and influence of global climate cycles. Nature 356, 786-788.

Feng, Z., Huang, Y., Feng, Y., Ogura, N., Zhang, F., 2001. Chemical composition of precipitation in Beijing area, northern China. Water, Air, \& Soil Pollution 125, 345-356.

Fujita, S., Tanahashi, A., Weng, J.H., Huang, L.F., Kim, H.K., Li, C.K., Huang, F.T.C., Jeng, F.T., 2000. Precipitation chemistry in East Asia. Atmospheric Environment 34, 525-537.

Galloway, J.N., Savoie, D.L., Keene, W.C., Prospero, J.M., 1993. The temporal and spatial variability of scavenging ratios for nss sulfate, nitrate, methanesulfonate and sodium in the atmosphere over the North Atlantic Ocean. Atmospheric Environment 27A, 235-250.

Han, G., Liu, C.-Q., 2006. Strontium isotope and major ion chemistry of the rainwaters from Guiyang, Guizhou Province, China. Science of the Total Environment 364, 165-174.

Han, Y.X., Xi, X.X., Song, L.C., Ye, Y.H., Li, Y.H., 2004. Spatio-temporal sanddust distribution in Qinghai-Tibet Plateau and its climatic significance. Journal of Desert Research 25, 588-592.

Hedin, L.O., Likens, G.E., 1996. Atmospheric dust and acid rain. Scientific American 275, 88-92.

Herut, B., Starinsky, A., Katz, A., 1993. Strontium in rainwater from Israel: sources, isotopes and chemistry. Earth and Planetary Science Letters 120, 77-84.

Hofmann, E.J., Hofmann, G.L., Fletcher, I.S., Duce, R.A., 1977. Further consideration of alkali and alkaline earth geochemistry of marine aerosols, results of a study of marine aerosols collected on Bermuda. Atmospheric Environment 11, 373-377.

Huang, K., Zhuang, G., Xu, C., Wang, Y., Tang, A., 2008. The chemistry of the severe acidic precipitation in Shanghai, China. Atmospheric Research 89, 149-160.

Kanayama, S., Yabuki, S., Yanagisawa, F., Motoyama, R., 2002. The chemical and strontium isotope composition of atmospheric aerosols over Japan: the contribution of long-range-transported Asian dust (Kosa). Atmospheric Environment 36, 5159-5175.

Khare, P., Goel, A., Patel, D., Behari, J., 2004. Chemical characterization of rainwater at a developing urban habitat of Northern India. Atmospheric Research 69, 135-145.

Kumar, R., Rani, A., Singh, S.P., Maharaj, K., Srivastava, S.S., 2002. A long term study on chemical composition of rainwater at Dayalbagh, a suburban site of semiarid region. Journal of Atmospheric Chemistry 41, 265-279.

Larssen, T., Carmichael, G.R., 2000. Acid rain and acidification in China: the importance of base cation deposition. Environmental Pollution 110, 89-102.

Larssen, T., Lydersen, E., Tang, D., He, Y., Gao, J., Liu, H., Duan, L., Seip, H.M., 2006. Acid rain in China. Environmental Science \& Technology 40, 418-425.

Li, C., Kang, S., Zhang, Q., Kaspari, S., 2007. Major ionic composition in the Nam Co region, Central Tibetan Plateau. Atmospheric Research 85, $351-360$.

Liu, C.-Q., Zhang, J., Li, C., 1999. Variations in $\mathrm{CaCO}_{3}$ content and $\mathrm{Sr}$ isotopic composition of loess and records of paleoclimatic fluctuations. Chinese Science Bulletin 44, 1512-1516.

Liu, G., Zheng, L., Nurdan, S.D., Gao, L., Liu, J., Peng, Z., 2006. Health Effects of Arsenic, Fluorine, and Selenium from Indoor Burning of Chinese Coal. Reviews of Environmental Contamination and Toxicology, vol. 189. Springer, New York, pp. 89-106.

Luo, K.L., Xu, L., Li, R., 2002. Fluorine emission from combustion of steam coal of north China plate and northwest China. Chinese Science Bulletin 47, 1346-1350.

Mouli, P.C., Mohan, S.V., Reddy, S.J., 2005. Rainwater chemistry at a regional representative urban site: influence of terrestrial sources on ionic composition. Atmospheric Environment 39, 999-1008.

Nakano, T., Tanaka, T., 1997. Strontium isotope constraints on the seasonal variation of the provenance of base cations in rain water at Kawakami, central Japan. Atmospheric Environment 31, 4237-4245.

Nakano, T., Kasasaku, K., Minari, T., Statake, K., Yokoo, Y., Yamanaka, M., Ohde, S., 2000. Geochemical characteristics of wet precipitation on the deep-forest, mountains island of Yakushima, southern Japan, $\mathrm{Sr}$ isotopic signature of plant-derived Ca in rain. Global Environmental Research 4, 39-48.

Nakano, T., Jeon, S.R., Shindo, J., Fumoto, T., Okada, N., Shimada, J., 2001. Sr isotopic signature of plant-derived $\mathrm{Ca}$ in rain. Water, Air, and Soil Pollution 130, 733-738. 
Nakano, T., Yokoo, Y., Nishikawa, M., Koyanagi, H., 2004. Regional Sr-Nd isotopic ratios of soil minerals in north China as Asian dust fingerprints. Atmospheric Environment 38, 3061-3067.

Nakano, T., Morohashi, S., Yasuda, H., Sakai, M., Aizawa, S., Shichi, K., Mrisawa, T., Takahashi, M., Sanada, M., Matsuura, Y., Sakai, H., Akama, A. Okada, N., 2006. Determination of seasonal and regional variation in the provenance of dissolved cations in rain in Japan based on $\mathrm{Sr}$ and $\mathrm{Pb}$ isotopes. Atmospheric Environment 40, 7409-7420.

Negrel, P., Deschamps, P., 1996. Natural and anthropogenic budgets of a small watershed in the Massif Central (France): chemical and strontium isotopic characterization in water and sediments. Aquatic Geochemistry 2, 1-27.

Negrel, P., Roy, S., 1998. Chemistry of rainwater in the Massif Central (France): a strontium isotope and major element study. Applied Geochemistry 13 , 941-952.

Negrel, P., Guerrot, C., Millot, R., 2007. Chemical and strontium isotope characterization of rainwater in France: influence of sources and Hydrogeochemical implications. Isotopes in Environmental and Health Studies 43, 179-196.

Okuda, A., Yabuki, S., Liu, C.-Q., Huang, Z.-W., 1992. Distribution of saltconstituting chemical species in the desert soils of the Turpan Basin and Junggar Basin, Xinjiang, China. Journal of Arid Land Studies 2, 29-37.

Parmer, M.R., Edmond, J.M., 1989. The strontium isotope budget of the modern ocean. Earth and Planetary Science Letters 92, 11-26.

Rastogi, N., Sarin, M.M., 2005. Chemical characteristics of individual rain events from a semi-arid region in India: three-year study. Atmospheric Environment 39, 3313-3323.

Roy, S., Negrel, P., 2001. A Pb isotope and trace element study of rainwater from the Massif Central (France). Science of the Total Environment 277, 225-239.

Schmitt, A.D., Stille, P., 2005. The source of calcium in wet atmospheric deposits: Ca-Sr isotope evidence. Geochimica et Cosmochemica Acta 69, 3463-3468.

Sequeira, R., 1993. On the large-scale impact of arid dust on precipitation chemistry of the continental Northern Hemisphere. Atmospheric Environment 27A, 1553-1565.
Topcu, S., Incecik, S., Atimtay, A.T., 2002. Chemical composition of rainwater at EMEP station in Ankara, Turkey. Atmospheric Research 65, 77-92.

Tu, J., Wang, H., Zhang, Z., Jin, X., Li, W., 2005. Trends in chemical composition of precipitation in Nanjing, China, during 1992-2003. Atmospheric Research 73, 283-298.

Wang, W., Wang, T., 1995. On the origin and the trend of acid precipitation in China. Water, Air and Soil Pollution 85, 2295-2300.

$\mathrm{Xu}, \mathrm{Z}$., Han, G., 2009. Chemical and strontium isotope characterization of rainwater in Beijing, China. Atmospheric Environment 43, 1954-1961.

Yokoo, Y., Nakano, T., Nishikawa, M., Quan, H., 2001. The importance of Sr isotopic compositions as an indicator of acid-soluble minerals in arid soils in China. Water, Air, and Soil Pollution 130, 763-768.

Yokoo, Y., Nakano, T., Nishikawa, M., Quan, H., 2004. Mineralogical variation of $\mathrm{Sr}-\mathrm{Nd}$ isotopic and elemental compositions in loess and desert and from the central Loess Plateau in China as a provenance tracer of wet and dry deposition in the northwestern Pacific. Chemical Geology 204, 45-62.

Yu, S., Gao, C., Cheng, Z., Cheng, X., Cheng, S., Xiao, J., Ye, W., 1998. An analysis of chemical composition of different rain types in 'Minnan Golden Triangle' region in the southeastern coast of China. Atmospheric Research 47-48, 245-269.

Zhang, D., Iwasaka, Y., 1999. Nitrate and sulfate in individual Asian duststorm particles in Beijing, China in spring of 1995 and 1996. Atmospheric Environment 33, 3213-3223.

Zhang, J., Takahashi, H., Wushiki, S., Yabuki, S., Xiong, J.-M., Masuda, A., 1995. Water geochemistry of the rivers around the Taklimakan Desert (NW China): crustal weathering and evaporation processes in arid land. Chemical Geology 119, 225-237.

Zhang, D.D., Jim, C.Y., Peart, M.R., Shi, C., 2003a. Rapid changes of precipitation $\mathrm{pH}$ in Qinghai Province, the northeastern Tibetan Plateau. Science of the Total Environment 305, 241-248.

Zhang, D.D., Peart, M.R., Jim, C.Y., He, Y.Q., Li, B.S., Chen, J.A., 2003b. Precipitation chemistry of Lhasa and other remote towns, Tibet. Atmospheric Environment 37, 231-240.

Zhao, D., Xiong, J., Xu, Y., Chan, W., 1988. Acid rain in southwestern China. Atmospheric Environment 22, 349-358. 